\title{
Chapter 11 \\ The Logic and Practices of Governments Providing Financial Support for Non-government Education
}

\author{
Hua Wu and Xi Wang
}

Government funding for private education is a global phenomenon (Glenn and Groof 2012). Non-government (Minban) education is literally private education in China. Passed on December 28, 2002, the Non-government Education Promotion Law of People's Republic of China affirmed the legitimacy of government funding for non-government education (Chap. 7: Support and Reward). However, the content of this law was primarily focused on funding for private schools and contained numerous limitations in terms of specific concepts and policy design (Ministry of Education of the People's Republic of China 2002). ${ }^{1}$ While the 2010 Outline of National Medium and Long-Term Education Reform and Development Plan (2010-2020) sought to improve the situation of public funding for non-government education through the provision of supporting policies, the funding only targeted private schools (State Council of the People's Republic of China 2010). Despite clarifying the modes of providing financial support, the funding target delineated by On the Revision of the Non-government Education Promotion Law by the Standing Committee of the National People's Congress (adopted on November 7, 2016) remained confined to private schools (National People's Congress of the People's Republic of China 2016). Essentially, narrowing the concept of funding for nongovernment education to that for non-government schools constitutes a major flaw in the legislation and policy practice of educational finance policies for nongovernment education. It also indicates that the government lacks a comprehensive

\footnotetext{
${ }^{1}$ Funding for non-government education includes funding for both non-government school students and schools. As such, funding for non-government schools is only one of the two ways to financially support non-government education and includes direct financial allocation, sharing of school costs, and sharing of teacher resources. While tax breaks, commissioned schools, and government procurement are not typical means of financial support, they may be discussed in the general sense.
}

H. Wu $(\bowtie) \cdot X$. Wang

Department of Education, Zhejiang University, Hangzhou, Zhejiang, China

G. Fan, T. S. Popkewitz (eds.), Handbook of Education Policy Studies,

https://doi.org/10.1007/978-981-13-8347-2_11 
understanding of the logic of policy design with regard to the financial support of non-government education.

\subsection{The Rationale of Government Financial Support for Non-government Education}

In Mainland China, there remains a widespread dispute regarding whether the government should provide non-government education with financial support and how to do so. In terms of the law, the legitimacy of and policy framework for providing such support has been made abundantly clear, and there are various policy practices across the country. Indeed, local governments' policy design can differ significantly in terms of whether they provide such support, as well as the ways and degree to which they do so. Connected to the local socio-economic development, these differences suggest that local governments think differently with regard to the necessity and rationality of financial support for non-government education. It is necessary to systematically elaborate the rationality for the government to financially support non-government education, which may also facilitate the formation of policy consensus and improve policy design. This section explores five reasons in greater detail.

\section{The First Reason to Financially Support Non-government Education Concerns the Equal Rights of All Students in Receiving Compulsory Education According to the Constitution of People's Republic of China and Education Law of People's Republic of China, all students have the same rights of access to education, regard- less of whether they attend public or private schools. Therefore, funding non- government education through the provision of financial support for the students in non-government schools is legally and constitutionally justified. ${ }^{2}$}

However, the provision of financial aid based on the equal rights of students in various local practices is minimal. Influenced by the ideology of planned economy and public ownership, people have long equated public education funding with public school funding and considered the public funding of public schools and private students as dependent upon the relationship of power rather than function. This misconception of the functional departments in question has resulted in the complete lack of funding for private school students-even compulsory private education-for a very long time (Wu 2006, 2007b). Fortunately, there was a shift in policy in 2015. In the Notice of the State Council on Further Improving the Urban and Rural Educational Expenditure Assurance Mechanism (State Council issued [2015]67), the State Council included private schools in compulsory education under the scope of public funding for the first time. They also differentiated between

\footnotetext{
${ }^{2}$ See Article 33 and Article 46 in Constitution of People's Republic of China and Article9, Article 37 in Education Law of People's Republic of China, and Article 5 and Article 27 in Non-government Education Promotion Law of People's Republic of China.
} 
the funding in terms of exempting tuition fees and that of providing public funds for students in non-government schools on a per capita basis. The publication and implementation of this notice has transformed educational finance from public school to public education finance. Moreover, the government since formally placed the financing of non-government education based on student rights on its agenda.

\section{The Second Reason to Financially Support Non-government Education Is}

Based on Its Financial Contribution According to the Communiqué of National Education Development Statistics 2015, there were approximately 162,700 nongovernment schools or institutions, with some 45.7 million enrolled students, in mainland China in 2015 (Table 11.1). Moreover, according to the Communiqué of the Ministry of Education, National Bureau of Statistics, and Ministry of Finance on Execution Statistics of National Education Funds in 2015, the average public education finance budget was CNY 8838.44 per primary school student; CNY 12,105.08 per junior school student; CNY 10,820.96 per senior secondary school student;

Table 11.1 Estimated 2015 national finance contribution by non-government education

\begin{tabular}{|c|c|c|c|c|c|c|c|}
\hline & $\begin{array}{l}\text { Primary } \\
\text { schools }\end{array}$ & $\begin{array}{l}\text { Junior } \\
\text { secondary } \\
\text { schools }\end{array}$ & $\begin{array}{l}\text { Senior } \\
\text { secondary } \\
\text { schools }\end{array}$ & $\begin{array}{l}\text { Vocational } \\
\text { secondary } \\
\text { schools }\end{array}$ & $\begin{array}{l}\text { Regular } \\
\text { HEIs }\end{array}$ & $\begin{array}{l}\text { Preschool } \\
\text { education } \\
\text { institutions }\end{array}$ & Total \\
\hline $\begin{array}{l}\text { Students of } \\
\text { non- } \\
\text { government } \\
\text { schools } \\
\text { (thousand } \\
\text { persons) }\end{array}$ & 7138.20 & 5029.30 & 2569.60 & 1833.70 & 6109.00 & $23,024.40$ & $45,704.20$ \\
\hline $\begin{array}{l}\text { Average } \\
\text { finance } \\
\text { budget for } \\
\text { public school } \\
\text { students } \\
(\mathrm{CNY})\end{array}$ & 8838.44 & $12,105.08$ & $10,820.96$ & $10,961.07$ & $18,143.57$ & $7248.43^{*}$ & $68,117.55$ \\
\hline $\begin{array}{l}\text { Money saved } \\
\text { by non- } \\
\text { government } \\
\text { education for } \\
\text { public } \\
\text { education } \\
\text { finance } \\
\text { budget } \\
\text { (CNY in } \\
\text { billion) }\end{array}$ & 63.09 & 60.88 & 27.81 & 22.93 & 110.84 & 166.89 & 452.44 \\
\hline
\end{tabular}

Resources: Communiqué of the Ministry of Education on National Education Finance Statistics 2016 (MoE 2017), Communiqué on National Education Development Statistics 2015 (MoE 2016a), Communiqué of the Ministry of Education, National Bureau of Statistics, Ministry of Finance on Execution Statistics of National Education Funds in 2015 (MoE 2016b). *The statistics of preschool education were summarized from the Communiqué of the Ministry of Education on National Education Finance Statistics 2016, prior to which there are no available preschool education statistics. 
CNY 10,961.07 per secondary vocational school student; and CNY 18,143.57 per student in a regular higher education institution. As such, non-government education saved the 2015 public education finance budget over CNY 280 billion (excluding preschool education); if preschool education is added into account, this figure increases to some CNY 450 billion (see Table 11.1). This accounted for $15 \%$ of the national public education finance budget and matched the ratio of students enrolled in non-government schools (17\%), indicating that if all education services were provided by public schools, the state may need to increase the public education finance budget by a further CNY 450 billion.

Thus, from the government's perspective, the most acceptable reason for the state to increase its direct financial allocation for private education is based on its contribution to the public education finance budget. This is also a popular idea among scholars (Wen 2004; Guan and Xiao 2006; Xie 2009; Lu 2011; Li and Zhang 2012; Wu and Wei 2012; Fang 2017).

\section{The Third Reason to Financially Support Non-government Education} Concerns the Externality of Education The government should provide financial support for public schools because that education may benefit both the students and the society, which means that education has a positive externality. Since nongovernment schools also provide such educational services and activities and have the same kind of social function and value, they should receive the same financial support provided to public schools.

\section{The Fourth Reason to Financially Support Non-government Education Is} Based on Its Efficiency The compulsory education sector illustrates this point. Approximately 12.17 million students studied in non-government schools in 2015; if public schools were required to take in these students, more than CNY 123.97 billion would be needed from the public education finance budget. However, nongovernment schools provided the same, if not better, educational service at the cost of only $10 \%$ of the public education finance budget. ${ }^{3}$ Since there is no doubt that non-government education can provide the same public goods for society, it is reasonable to provide financial support for those non-government schools - or at least no less reasonable than providing financial support for public schools - on the basis of improving the efficiency of the allocation of public financial resources. ${ }^{4}$

\footnotetext{
${ }^{3}$ In the most optimistic estimated situation, if the Notice of the State Council on Further Improving the Urban and Rural Educational Expenditure Assurance Mechanism (State Council issued [2015]67) was fully implemented by all local governments, the financial support for non-government education would not exceed that for public school education. As such, the actual situation would likely be worse.

${ }^{4}$ The contribution by non-government education to improving education equity was often overlooked or misunderstood. As a matter of fact, the development of non-government education made it possible for the government to increase investment in education in less-developed areas, lowperforming schools, and disadvantaged groups. This means that the development of non-government education has helped to form the Pareto Improvement. In the meantime, the parents and students who willingly chose to attend non-government schools to obtain better education have
} 


\section{The Fifth Reason to Financially Support Non-government Education Is Based on Maintaining and Improving the Educational Competitiveness of the} Nation In countries around the world, the singular public school education system has proved unable to meet the needs of a developing modern society and education. With the reform and opening up of China, ensuring the healthy and sustainable development of non-government education has become an important part of the national macroscopical strategy beyond the needs of education itself. As noted in the Outline of National Medium and Long-Term Education Reform and Development Plan (2010-2020), non-government education constitutes an important growth point in the development of education and an important force in the promotion of educational reform (State Council of the People's Republic of China 2010). Moreover, since the cost of education activities is continuously increasing, if the government does not commit to covering part of the cost of running non-government schools, the majority of those schools may face closure (Wu 2007a). As such, using public funding to support the development of non-government education may be regarded as necessary to maintain the healthy operation of the modern education system.

While there are many reasons to provide financial support for non-government education in the policies and practices across mainland China, the aforementioned reasons cover the important aspects for the purposes of this analysis.

To better understand these reasons, however, it is worth considering the opposing views. The value of non-government education in improving the quality of education and social development has been recognized since the implementation of the Non-government Education Promotion Law. Arguments against the financial support of non-government education based solely on ideological conflict are no longer common; rather, opposition is predominantly based on questioning the necessity and rationality of doing so.

\section{The First Reason to Oppose Financial Support for Non-government Education}

Is the So-Called Waiver of Rights This view holds that the current education finance system does not discriminate against non-government education and that public schools have provided open access to all students-including those in nongovernment schools, who can receive the same financial support if they choose public schools. As such, the students themselves opted to give up their rights when they chose to attend a private school. Consequently, there is no need to financially support non-government education based on the equal rights of students. However, this view fails to consider that the right of students to receive public financial support is not based on the premise of studying in public schools. Moreover, there is no legal ground for this viewpoint in the Constitution, Education Law, or the Nongovernment Education Promotion Law.

contributed to equity in the educational outcome in terms of benefitting students' personal development. 


\section{The Second Reason to Oppose Financial Support for Non-government} Education is Called the Insufficient Financial Resources theory This viewpoint is particularly popular in education administrative departments. This view typically asserts that, "Even public schools are currently underfunded, where can more funding be found to support non-government schools?" This kind of statement, and which is a clear discrimination or violation of the law, makes people wonder why financial support for non-government schools need to wait until the funding for public schools is adequate. It also prompts questions of when public schools will be adequately funded, and why non-government schools are not treated equally when they produce the same social value.

\section{The Third Reason to Oppose Financial Support for Non-government Education}

Is Called the Non-Profit Principle While this viewpoint is not opposed to the provision of financial support for non-government education on the surface, it emphasizes that financial support should be given on the premise of the classified management of non-government schools-inferring that public finance should only be provided and increased for non-profit non-government schools. With regard to for-profit non-government institutions, in addition to never funding them, this perspective holds that the government treat them like common enterprises and levy turnover and corporate income tax from them. This view is common among fiscal and taxation departments of the government. The Decision of the Standing Committee of the National People's Congress on Amending the Non-government education Promotion Law was passed on November 7, 2016; although there is no direct stipulation that local governments not provide financial funding for for-profit non-government schools, a similar tendency has already been shown. ${ }^{5}$ However, if we understand that financial support for non-government education cannot be confined to the financial support for non-government schools, then the non-profit principle-which confines financial support for non-government education to that for non-profit non-government schools-would lose ground.

The discussion of the pros and cons of this issue shows that both the supporters and detractors have their own reasons. As such, it is necessary to search for a position that is beyond the special interests of certain groups and reanalyze this issue from the perspective of public interest. In addition to providing a logical stance from which to discuss the question of whether the government should provide financial support for non-government education, an analysis based on public interest also serves as a starting point from which to evaluate the rationality of all public policies.

\footnotetext{
${ }^{5}$ Article 7 of the Decision of the Standing Committee of the National People's Congress on Amending the Non-government Education Promotion Law states that: "People's government at or above the county level could support non-government schools through means of service purchasing, student loans, scholarships and lease or transfer of state-owned assets; for non-profit nongovernment schools, the government could also support their development by providing subsidies, reward funds and donation rewards." This implicitly reflects the non-profit principle.
} 


\subsection{Policy Logic of Public Finance Support for Non-government Education: Public Interest}

In modern democratic society, a reasonable public policy should be based on the purpose of increasing public interest-otherwise it would be unreasonable or unnecessary. ${ }^{6}$ From the perspective of public policy design, there are three basic types of public interest (Wu and Wei 2012). First, public interest that benefits all. In China, this includes the overall improvement of the social development environment due to institutional change, the transformation of the market economy through China's reform and opening up, China's joining in the World Trade Organization (WTO), as well as the establishment of social security system and free compulsory education system. A public policy can be considered reasonable if it helps form such public interest. Second, public interest that benefits part of the population and imposes no good or harm on others, and which forms the well-known Pareto Improvement. This includes the unifying of separate pension systems, provision of social assistance for disadvantaged groups, and all kinds of industry support policies. Although the rationality of such policies is likely to be controversial, they are reasonable if they can be explained in terms of basic social values, as well as the overall and long-term interests of social development. Third, public interest that benefits some yet harms others, such as price control and progressive tax systems. This kind of policy is highly controversial - except in situations where the rich are robbed to feed the poor. In terms of normative analysis, the legitimacy of a policy will be called into doubt if it cannot be explained by any one of these three types of public interest. With regard to the issue discussed in this chapter, the analytical framework of public interest is also applicable.

Does providing financial support for non-government education help generate the first kind of public interest? To better illustrate the point, another one should be asked first: Does non-government education generate the first kind of public interest? Indeed, the emergence of non-government education has greatly increased education resources, improved the efficiency and equity of education, expanded the scope of educational choice, and promoted the innovation of education systemthus making the education system more dynamic and vigorous overall. Therefore, financial support from the government would benefit the healthy and sustainable development of non-government education and improve the likelihood of generating more public interest.

Does providing financial support for non-government education help generate the second kind of public interest? The most unique characteristic and significant advantage of non-government education is that both the schools as well as the parents and students who chose to attend the schools were free to do so, thus ensuring the satisfaction of those parents and students and increasing their educational

\footnotetext{
${ }^{6}$ This does not mean that the government should introduce public policies for all kinds of potential public interest, which is neither necessary nor possible. Rather, public interest should be the basis of policymaking for each and every public policy introduced by the government.
} 
interest. Moreover, their decision to attend a private school had no impact on those in public schools, making this process a typical case of Pareto Improvement.

Finally, does providing financial support for non-government education help generate the third kind of public interest? The answer is also positive. On the surface, if the government provides financial support for non-government education, the financial resources for public schools would be bound to decrease-making public school education a victim of this policy. However, a more critical understanding of this situation reveals that most non-government schools struggle to maintain sustainable development without financial support from the government. Ultimately, if these non-government schools are closed, the government would have to build more public schools, and the average financial assistance to all these schools would be even less as a result. Moreover, if the government provided more financial support for non-government schools for migrant children from rural to urban areas, the third kind of public interest generated from this kind of policy would be particularly self-evident.

The discussion above does not distinguish between the specific sectors of nongovernment education, which may raise the concern that it is unnecessary to delineate between formal and informal education, early childhood and higher education, or non- and for-profit institutions when talking about providing financial support for non-government education. While such concerns are common, the dispute here is about whether the government should financially support non-government education and the degree to which they should do so, as well as the legitimacy and rationality of this idea. Whether a certain local government in mainland China should introduce and implement such supporting policies and how these may be subject to elements - like the local economy, social development, local politics, and culturelies beyond the scope of this chapter. Furthermore, this chapter discusses an issue that is not influenced by the differences between specific sectors of non-government education; therefore, the conclusion is not influenced by its failure to distinguish these aspects.

Thus, in narrowing the scope of our discussion, it is sufficient to assert that all non-government education sectors corresponding to public education sectors should be in the place to receive public financial support from the government. After all, the government supports public schools due to the public interest they produce, and non-government schools could produce the same-if not more-public interest. While many people pay much attention to the issue regarding whether for- and nonprofit schools should be treated equally in terms of state financial support, the quality of educational services is not influenced by whether the school was non-profit. As such, it should not be reasonable to deprive the rights of students in for-profit non-government schools.

Moreover, in terms of industrial policy, the government's financial support of for-profit educational institutions is merely the concrete application of its strategic industry supporting policies, like those concerning tax relief. Furthermore, the government does not necessarily choose to provide financial support whenever public interest exists. As evidenced throughout the reform and opening-up over the last three decades, public interest is more likely to be obtained through the construction 
of a legal system and the positive effects of the market mechanism, rather than solely through financial support. In short, discussing financial support for nongovernment education from the perspective of public interest may have little to do with the distinction between different educational sectors.

As discussed above, the answer to whether the government should provide financial support for non-government education is quite clear: it is not only necessary but essential for the government to financially support non-government education. However, there are two more problems to be solved before this idea can be transformed into practical policy.

The first problem concerns the question of how much money the government should provide. This problem is relatively simple. In theory, the financial support for non-government education can be considered reasonable as long as it is not higher than the average public school student's share of financial resources. In terms of policy design, the financial contribution of the local non-government schools at various levels can be seen as the ceiling for state financial support. Considering the complexity of local interest patterns, game playing of local social forces, and differences in opinion at the local level, it is reasonable to start with a relatively low level of financial support in practice-such as $10 \%$ of the total financial contribution of local non-government education, increased on an annual basis.

The second problem is more complex and concerns how financial support should be provided. This chapter makes some suggestions. As noted, regardless of which type of financial support we choose, it must benefit the generation and expansion of public interest. Since real or potential public interest is only possible when nongovernment education develops healthily, the answer to this question may be that the choice of the specific forms of subsidization should be realistic and reasonable for promoting the development of local non-government education. This means that the policy feasible in one city or period may not be suitable for another. As such, two kinds of policy design should be considered when discussing financial support from the perspective of facilitating the development of local non-government education: namely, the guaranteeing of student rights and the sharing of non-government school costs. We should also place greater attention on financial support policies that aim to subsidize students in non-government schools.

From the perspective of juridical logic, public education funding should be shared by all people and should not exclude those who choose to study at nongovernment schools. However, this is the current situation faced by students in nongovernment schools, who are excluded from public education finance as a result of their school choice. Therefore, endeavors for the provision of more financial support for non-government education must be based on students' rights. Failure to do so will result in the legitimacy of such proposals being questioned and the construction of a healthy policy environment for non-government education losing its most important conceptual ground. Although Section 2, Article 43, of the Outline of National Medium and Long-Term Education Reform and Development Plan (2010-2020) (State Council of the People's Republic of China 2010) reiterated that non-government schools, students, and teachers should have the same legal status as those of public schools and ensured the autonomy of non-government schools, the 
discriminating policies toward non-government schools embedded in this government document should be removed. Since it appears that the policymakers were not overly concerned with such discrimination, the policies that require refinement are those pertaining to non-government schools.

Meanwhile, emphasis on understanding non-government school students as the object of financial support policies also has a direct market value. Compared with public schools, the high charge of non-government schools is a typical market characteristic that has greatly weakened the competitiveness of non-government schools. However, if the government provides financial aid for non-government school students in an amount no higher than that for public school students, it could offset the tuition and fees of non-government school students and greatly relieve the economic pressure on their families. Since more families will not surrender the opportunity of studying in high-quality non-government schools because of economic reasons, this could also improve the structure of student enrollment and expand the market space for non-government schools.

In addition to the two aspects mentioned above, the financial support policies for non-government education could also be combined with other policy objectivessuch as rewarding non-government schools of different types according to their quality and efficiency, introducing industry-oriented policies to guide the adjustment of industry layout, and promoting the survival of the fittest among nongovernment schools. Government procurement from qualified non-government schools able to provide educational products (like school places) could also be regarded as financial support in terms of sharing school costs. As it has the least degree of conflict with the current fiscal system, this policy practice could be worth promoting. ${ }^{7}$

\subsection{Case Studies on the Public Financial Support for Non-government Education: Zhejiang Province, China}

While the question of whether the government should subsidize non-government education remains contentious, policies and practices have been actively promoted by local governments. To illustrate the dynamics of these policies and practices, this section uses Zhejiang Province in mainland China as a case study (Non-government

\footnotetext{
${ }^{7}$ Strictly speaking, government procurement of school places is a type of transaction rather than financial assistance. Moreover, the current actual payment of government procurement is usually below average student costs in non-government schools, and even below those in public schools (in other kinds of government procurement, the government is usually willing to pay more than the market price of certain products). Thus, it is clear that the government has received financial support from non-government schools rather than the other way around. However, the Halo Effect, which non-government schools received through government procurement, made it tempting because it showed that the educational products it provided were highly recognized.
} 
Education Association of Zhejiang Province and China Non-government Education Research Institute Zhejiang Branch 2011). As a microcosm of the policies and practices across the country, Zhejiang Province also evidences what we have discussed above.

There are three kinds of policies regarding the provision of financial assistance to non-government educational institutions by local governments in Zhejiang Province.

The first is voucher based on the guarantee of student rights Represented by various voucher programs, the philosophy of this policy model is that all students share equal educational rights, as guaranteed by the Non-government Education Promotion Law and the Compulsory Education Law. This policy model is essentially characterized by the allocation of public finance for education through vouchers given to students in non-government schools, showing that the government is willing to provide financial support for non-government school students based on their educational rights.

Adopted from the United States, this education voucher program was first introduced in Changxing County. In 2001, as stipulated in Notice of the Education Commission in Changxing County on How to Use an Education Voucher, every freshman who attended a non-government compulsory education school could receive an education voucher to the value of CNY 500, while every freshman who attended a vocational school could receive one with the value of CNY 300. As stipulated in Rules for the Implementation of Financial Aid for Poor Students in Changxing County, from the autumn of 2002, poor students in primary schools could get an education voucher of CNY 200 per semester, and poor students in junior secondary schools could receive one of CNY 300. Influenced by the success of this program in Changxing, other cities, and counties began introducing various education voucher programs-such as community education vouchers in Shangcheng District, Hangzhou City; Migrant Workers Training Vouchers in Quzhou City; Preschool Education Vouchers in Beilun District, Ningbo City; and Education Subsidies Vouchers in Rui' an City, Wenzhou City. Although the amount of those vouchers was not particularly large and most have since been cancelled, these programs spread the idea that all the students have equal educational rights and that non-government schools could also share in public financial resources, thus playing a positive role in improving public opinion (Wu and Wei 2012).

The second policy practice is based on sharing of school costs Represented by the Ningbo Non-government Education Promotion Act and the Provisions on Implementation of the Ningbo Non-government Education Promotion Act by Ningbo Municipal People's Government, Zhejiang Province (Ningbo Municipal People's Government issued [2007]58), this policy reflected a philosophy that public and private schools play the same role in education and that the reasoning behind the government provision of financial support for public school education also stood for non-government education. With the provisions in the Non-government Education Promotion Law and the Compulsory Education Law, this model was characterized 
by the allocation of public education funding directly to non-government schools according to specific standards. As such, this policy model supported nongovernment schools by sharing their costs.

As stipulated in the Ningbo Non-government Education Promotion Act of 2006, city and county governments (county-level cities or districts) must set up special funds to support the development of non-government education. There are currently two kinds of supporting policies for non-government education in Ningbo. The first is intended for compulsory and secondary vocational education schools that meet the prescribed requirements, with the government providing a quarter of the finance assistance given to the same kinds of public schools. The second policy is directed toward non-government formal education schools and preschools that pay social security fees for teachers with professional or technical positions, with the government supplying half the total payment given to their public counterparts. The government provided CNY 10.1 million in 2007, CNY 12 million in 2008, and CNY 14.3 million in 2009 , for five municipally approved non-government schools.

The aforementioned policy design was also applied in other cities. For example, Suggestions of the Anji County People's Government on Promoting the Development of Non-government Education (Anji County People's Government issued [2010]62) stipulates that the county government provides financial subsidies based on the amount of social security fees paid by non-government institutions that meet the prescribed requirements. This results in their subsidizing up to $30 \%$ of the total amount paid by non-government junior high schools, and 50\% of that paid by nongovernment compulsory education schools and preschools.

Moreover, Suggestions of the Lishui Municipal People's Government on promoting the Development of Non-government Education (Lishui Municipal People's Government issued [2010]41) mandates that the government covers $30 \%$ of the costs involved in providing social security fees for teachers with professional or technical positions at non-government schools that pay for various kinds of social insurance for their staff. For instance, the government provides 30\% of the amount paid by kindergartens for the prescribed social security fees for their teachers, qualified healthcare workers, and cleaners who meet the employment standards of the administrative departments of education, were examined and approved by those departments, and held a teacher's certification.

The third policy practice involves rewards based on performance The government provides a monetary bonus for excellent non-government schools, thereby facilitating a policy of the survival of the fittest among non-government schools. This policy model is characterized by assessment of the quality and efficiency of non-government schools in order to judge whether it merits the corresponding performance reward. This has been a primary means of providing financial support for non-government education in many Chinese cities.

In 2001, the Taizhou Municipal People's Government declared that all nongovernment schools or institutions elected as outstanding institutions at the national, provincial, or municipal level would receive a reward from the government based on 
the number of teachers employed, the annual amount of a public school teacher's salary multiplied by a third, two thirds, or half the number of the teachers. Moreover, non-government schools that own their premises and provide formal or preschool education could receive financial support from the government as a reward rather than subsidies if they recruit students and run the schools according to the laws and regulations. Consequently, non-government schools with more than 1000, 1500, or 2000 students could receive an annual reward of CNY 50,000, CNY 100,000, or CNY 150,000, respectively.

In 2005, the Lishui Municipal People's Government declared that nongovernment schools elected as national quality schools could receive a one-time reward of CNY 500,000. Meanwhile, those elected as the first, second, and third rank provincial and municipal quality schools could receive a one-time reward of CNY 300,000, CNY 200,000, and CNY 100,000, respectively. Additionally, they would receive an annual reward based on the number of teachers used, with an average amount of public school teacher's salary multiplied by one third, two thirds, or half the total number of teachers employed.

In 2010, Suggestions of the Anji County People's Government on Promoting the Development of Non-government Education (Anji County People's Government issued [2010]62) stipulated that the government set up a special fund of CNY 1 million to reward well-managed, high-quality, and unique non-government institutions, as well as groups or individuals who contributed significantly to nongovernment education courses. Non-government schools elected as outstanding institutions at the national, provincial, or municipal level would receive a one-time reward of CNY 500,000, CNY 300,000, and CNY 100,000, respectively. It further stipulated that the amount of the reward increased annually according to the increase of municipal fiscal avenue. As such, the financial support policy in Anji County has replaced subsidies with rewards since 2010 .

In 2011, the government of Wenzhou City set up an annual special fund of CNY 30 million yuan for financial subsidies and rewards for non-government schools. This fund has since been used to reward non-government schools, investors, principals, and teachers ranked "excellent" in the annual inspection; subsidize teacher training sessions, teacher recruitment, as well as loans and interests for nongovernment schools; and reward the graduates of vocational junior and senior high schools.

In addition to the aforementioned policy practices of financial support, government procurement could constitute another means of subsidizing non-government schools. Indeed, the practice was observed in Wenzhou, Ningbo, and Taizhou, among other cities. However, government procurement is only feasible in a handful of high-quality non-government schools. Moreover, while the general financial support benefits non-government schools, government procurement is more of a market transaction between government and non-government schools. Nonetheless, these two types of financial support could be complementary and guide the healthy and sustainable development of non-government education. 


\subsection{International Experience of Financial Support for Non-government Education: The US, Australia, and The Netherlands}

As in the case of mainland China, there are numerous types and names for private education around the world-including the various independent, non-governmental, non-state, and private schools in the western countries, which are often related to religion. Since most western countries have a tradition of freedom of education and generally recognized the right of parents to choose non-government schools for their children, financial assistance policies for the government support of nongovernment education dates back to the early twentieth century in some countries. Demands regarding school choice have intensified in many countries over the past two decades, compelling governments to adjust public finance frameworks and develop increasing numbers of policy designs and practices to provide financial support for non-government education.

\subsubsection{Policy Logic of Public Finance Support for Non-government Education on a Global Scale}

As discussed earlier, the policy logic of public finance support for non-government education is based on public interest. According to the study of policy practices in other countries, this policy logic predominantly concerns two aspects: first, the promotion of equal education and reduction of socio-economic stratification; second, ensuring the freedom of school choice for citizens, especially those from disadvantaged groups. There have been several empirical reports and articles on both kinds of policies.

With regard to the promotion of equal education, the Organization for Economic Co-operation and Development (OECD) examined data from 65 countries and regions that took part in the 2009 Program for International Student Assessment (PISA), analyzing the management and funding of schools. This assessment is useful in understanding the policy logic of this practice. The OECD divided schools into two categories - namely publicly and privately managed schools, which may correspond to the complex situation of non-government education in mainland China. This report studied the relationship between public funding and socioeconomic stratification, concluding that the level of public funding for privately managed schools correlated to socio-economic stratification and that countries and regions that provided more public funding for privately managed schools tended to have less socio-economic stratification. The report further advances that it is essential to choose the most suitable means of providing public funding for privately managed schools (OECD 2012a, b: 47).

With regard to the second kind of policy practice, the OECD report analyzed the education voucher program — an important means of providing public support for 
non-government education-and introduced different policy practices in many countries. The result indicates that if there is no distinction in the distributing of vouchers, the policy practice will compound socio-economic stratification of the country (OECD 2012a, b: 36). This is why so many countries distribute education vouchers specifically to disadvantaged children, low-income families, and children in need of special education-thereby ensuring the freedom of school choice for all citizens.

\subsubsection{International Policy Practices and Guidelines for Public Funding to Support Non-government Education}

According to the OECD (2012a, b) report, while the level of public funding for nongovernment or privately managed schools varies across OECD and partner countries, the average amount of public funding accounts for approximately $58 \%$ of the school's total funding. In Sweden, Finland, the Netherlands, and the partner economy of Hong Kong-China, some $90 \%$ of privately managed school funding comes from the government. In contrast, $1 \%$ or less of the funding for privately managed schools in the United Kingdom, Greece, the United States, and Mexico comes from the government; while between just $1 \%$ and $10 \%$ of funding is provided by the government in New Zealand, Brazil, Chinese Taipei, and Shanghai-China (OECD 2012a, b: 21). These public funding policies do not include flexible supporting policies like the cost covered by the governments through tuition tax credits; they merely reflect the general level of a country's financial commitment to private schools (OECD 2012a, b: 32).

In summation, there are four main kinds of financial support for non-government education:

1. The allocation of direct public funding with reference to the form and amount of public funding for public schools.

2. Sharing of school costs through tax deductions for non-government schools.

3. Performance rewards according to the quality and efficiency of non-government schools.

4. Alternative funding policies that provide financial support for students and their parents, such as the education voucher program and tuition tax credits program.

Policy practices around the world tend to be a combination of the aforementioned policies. Certainly, all the four types of funding policies are observable in the case of Zhejiang Province, China. In addition, we selected three other countries as representatives to analyze the policy practices and guidelines for public funding to support non-government education: the United States, Australia, and the Netherlands. The ratio of non-government school funding provided by the government in these countries is almost 0\%, 55\%, and 97\%, respectively (OECD 2012a, b: 21, Fig. 1.3). 


\subsubsection{The United States}

In the 2013-2014 school year, private schools accounted for 25\% of all schools in the United States, while private school enrollment from pre-kindergarten to twelfth grade accounted for $10 \%$ of all the US students (Council for American Nongovernment education 2015). Although the OECD data showed almost no financial funding for non-government schools, the financial support for non-government education in the United States involved the second and fourth means of public funding: sharing the costs of non-government schools through tax deduction policies and providing alternative financial support—such as education vouchers for students and their parents - who chose to attend non-government schools.

For non-profit private schools in the United States, the Internal Revenue Code (IRC) 501(c) stipulated that charitable educational organizations were eligible to receive tax-deductible contributions, providing that no part of their net earnings benefitted any private shareholder or individual (Internal Revenue Service of the United States 2017). With regard to for-profit private schools, according to the State Regulation of Private Schools, there are 21 states-including Kansas, Colorado, and Illinois - that exempt real and personal property used solely for schools from taxation; some states exempt private schools from taxation in terms of the sale of food, textbooks, and service of school commuting buses. Funding for public schools mainly came from local tax revenue until in 1960s, when local tax revenue equaled state tax in the funding of public schools and property tax was the most important source of local tax revenue. In the 2013-2014 school year, 45.5\% of the funding for public schools came from local property tax (Snyder et al. 2016). Therefore, as a main source of funding for the public education system, the exemption of property tax indicates the financial support of local governments for non-government schools-especially for for-profit private schools that rarely enjoy tax cutting policies.

Moreover, although the US Constitution and other laws prohibit the use of public education funds for religious and other types of private schooling, there were numerous ways of financially supporting private schools in practice. These include education voucher, tuition tax credit, and education savings account programs-all of which aim to protect the freedom of school choice for parents and children.

The education voucher program was the earliest and most influential program for providing financial support for non-government schools and ensuring the freedom of school choice. Education-based vouchers were first introduced in the city of Milwaukee, Wisconsin, in 1990, to help children in failing public schools access better education. Fourteen states, as well as the District of Columbia, currently run education voucher programs. The main targets of these programs are students from low-income families, failing public schools, those with disabilities, and students living in rural areas (National Conference of State Legislatures 2017). Several states have opened the education voucher programs to middle-income families. For example, in Milwaukee, the number of students who have benefitted from the Milwaukee Parental Choice Program (MPCP) has increased annually since 1990. In the 2015-2016 school year, 117 non-government schools participated in the MPCP, 
while more than 27,000 students from families with an income lower than $300 \%$ of the federal poverty level have benefitted from this program. Indeed, the average amount of financial aid provided through a voucher is about $\$ 7,537$ (with a difference of about $\$ 600$ between students in grades K4-8 and students in grades 9-12) (Wisconsin Department of Public Instruction 2016).

The second kind of policy practice is a tuition tax credit program, which appears to have originated in Arizona in 1998. Since this program can use tax revenue for school choice before it is turned into public education funds, thereby incurring less governmental regulation for non-government schools, it has become a particularly popular policy practice in many states. In Arizona, for example, taxpayers can donate part of their income tax to School Tuition Organizations (STOs), which turns the taxes into tuition fees. Indeed, they may even receive a larger amount of money than they donated and use it as a means of paying the tuition for private schools. In addition to personal donations to STOs, there are chances for certain social groupslike families with children who have disabilities - to donate taxes and receive scholarships from STOs. In the 2014-2015 fiscal year, the donations to STOs totaled $\$ 140$ million, and every couple or joint taxpayers could receive an income tax credit for a donation of up to $\$ 1070$. At the same time, the Arizona Department of Revenue stipulated that $90 \%$ of the income of STOs should be used to provide scholarships for more than one non-government school and that the receivers of those scholarships should come from families with an income lower than 185\%, 185\%-342.25\%, or above $342.25 \%$ of the federal poverty level. The average amount of a scholarship that year was $\$ 1,846$, with each of the three income brackets receiving a third of the available scholarships. By 2015, STOs in Arizona had received donations of about $\$ 950$ million, with $\$ 780$ million used to provide scholarships to support study at private schools (Arizona Department of Revenue 2016).

Founded in 2001, the Pennsylvania's Educational Improvement Tax Credit Program (EITC) allows corporations to donate to non-profit Scholarship Organizations and Educational Improvement Organizations in order to provide scholarships for students from low-income families, thereby enabling their access to any public or private schools. With the maximum donation amount of $\$ 750,000$, approximately $75-90 \%$ of the donation can be used as a tax credit (Pennsylvania Department of Community and Economic Development 2017a). Pennsylvania introduced another tuition tax credit program called the Opportunity Scholarship Tax Credit Program (OSTC) in 2012. The OSTC allows eligible businesses to contribute to a Scholarship Organization in order to provide scholarships to eligible students residing within the boundaries of a low-achieving school, thereby enabling them to attend another public school outside of their district or a nonpublic school (Pennsylvania Department of Community and Economic Development 2017b). As such, in 2015,17 states transformed up to $\$ 830$ million in personal and corporate income tax into financial support for non-government schools in the form of tuition fees and scholarships, benefitting more than 234,000 students (The Foundation for Opportunity in Education 2013).

The education savings account program is the latest financial support program for non-government education. Started in Arizona in 2011, five states-including 
Florida and Mississippi-have introduced this program, while North Carolina is set to introduce the program and begin providing funding to students in the 2018-2019 school year (EdChoice, 2017). This program is typically targeted toward children with special needs, such as those with disabilities or various kinds of learning disorders, as well as children in failing public schools. Some states, including Nevada, have expanded the scope of this program to children who have been enrolled in public schools for more than 100 days, but felt unsatisfied with or could not be accommodated in the schools in question. With the permission of the government, this program allows parents to remove their children from their current school and for the quota of public education funds they have not used to be deposited into a restricted-use debit card. The family can then use this card for approved educational expenses, submitting the receipts to the approved administrative agent for quarterly audits. Approved educational expenses include costs of approved private schools, accredited and licensed therapists, tutors, online courses, and text books. Although this kind of program predominantly targets children with special needs, some states-like Arizona-have expanded the scope of support to all children enrolled in public schools (EdChoice 2016).

\subsubsection{Australia}

According to the data from the Australian Curriculum, Assessment, and Reporting Authority (ACARA), in 2016, there were 9414 primary, secondary, and special education schools in Australia. Approximately $30 \%$ of these were non-government schools (ACARA 2016a), accounting for 35\% of all students (ACARA 2016b). The Australian government supports a wide range of public and non-government schools through public funding and favors the direct allocation of funds to the schools. As stipulated in Australian Education Act 2013, government schools are approved and managed by the State or Territory authority and receive the majority of their public funding from their state or territory governments, with the Australian government providing supplementary funding. In contrast, non-government schools receive the majority of their public funding from the Australian government, with state and territory governments providing supplementary funding. Since 2014, public funding for non-government schools has been based on the Schooling Resource Standard (SRS) and the school's total loading for the year, including the extra costs incurred by students with disabilities, those with a low socioeconomic status, and those with poor English proficiency (Australian Government Department of Education and Training 2017). According to the provisions in Australian Education Act 2013 and Australian Education Regulation 2013, the Australian government provides public funding for participating government and non-government schools in accordance with the same guidelines. The funding formula is as follows (Australian Government 2013):

$\{[$ The number of students at the school for the year $*$ The SRS funding amount for the year for a student at the school $*(1-$ The school's capacity to contribute 
percentage)] + The school's total loading for the year $\} *$ The Commonwealth share for the school

The allocation for education from the Australian government and all state and territory governments totaled AUS\$ 50.4 billion for the 2013-2014 year. Funding from the federal government accounted for more than $27.2 \%$ of this amount and most was used to support non-government schools. The total amount of funding allocated to government schools was $\$ 38.5$ billion, which amounted to AUS $\$ 16,177$ on a student-per-capita basis - an increase of $4.5 \%$ compared to the previous school year. The total amount of funding for non-government schools was AUS $\$ 11.9$ billion, with AUS $\$ 9,327$ provided on a student-per-capita basis-marking an increase of $7.2 \%$ (ACARA 2014). Although there is a significant gap between education funding for government and non-government schools on a student-per-capita basis, there is a bigger increase in the amount of public funding received by nongovernment schools than by government schools.

\subsubsection{The Netherlands}

The Netherlands has one of the highest education performances in Europe. Indeed, PISA 2015 showed that 15-year-old teenagers in the Netherlands ranked 17th in science, 15th in reading, and 11th in mathematics-indicating that the cognitive abilities of Dutch students are among the highest in the world (OECD 2016a: 35). The Dutch education system is also superior in terms of equal educational opportunity and freedom of education. In the Netherlands, anyone is free to set up any type of school providing that it meets the standards of the Dutch education system. With due respect to individual right to freedom religion or belief, all non-government schools-including religious and secular schools-receive the same kind of public funding from the government. Derived from Article 23 of the Constitution of the Kingdom of the Netherlands, this policy dates back to 1917, when the Dutch education system was no longer monopolized by public schools. A century later, Dutch private schools outperform public schools with overwhelming advantages (Patrinos 2010). In 2013, about one third of students in primary education attended public schools, while the remaining two thirds were enrolled in Catholic, Protestant, and other types of private schools (OECD 2016a: 29-30). In other words, nongovernment education has acquired the dominant position in the Netherlands.

While all public and private schools in the Netherlands receive per capita funding, financial aid is adjusted according to various elements, including rural location, as well as the number of students with poor socio-economic backgrounds and special education needs. Based on the student population, block grants are given to school boards for staffing and operating costs. Schools can also receive additional funding for special educational purposes, such as students at risk of dropping out those in poor socio-economic conditions (OECD 2016a: 34). As such, public funding for non-government schools in the Netherlands favors the first type: money 
follows the students and each school receives a sum equivalent to the per capita cost of public schooling for each student enrolled (Patrinos 2010).

With regard to the decision-making for and management of schools, the Dutch education system is highly decentralized. While the education systems are decentralized in both the Netherlands and Finland, for example, most of the decisionmaking in the Finish system is decentralized to local municipal authorities and the schools have little autonomy as a result. In contrast, Dutch schools make approximately $86 \%$ of all decisions for themselves, which is the highest degree of independence among OECD countries (OECD 2012b: 500). Moreover, there is no national curriculum in the Netherlands: schools make all of the decisions with regard to issues concerning the organization of instruction, personnel management, and allocation of resources. This is also grounded in the principle of "freedom of education" guaranteed by the Dutch Constitution of 1917. In addition, private schools have even more autonomy than public schools insofar as public schools must admit any student, unless there is no place left, while private schools are in the position to refuse students who do not meet their standards or principles (OECD 2016a: 29). While this policy grants private school significant autonomy, it has also deepened the gap in student performance between schools to some extent, resulting in premature divergence among students and schools (OECD 2016b: 226).

Generally speaking, the approaches adopted by governments in the United States, Australia, and the Netherlands toward the funding of non-government schools were predominantly one or a combination of the first, third, and fourth type; it is rare to find policy practices in which the government provides rewards to nongovernment schools based on their performance. In the Chinese context, the amount of rewards based on performance was relatively small and given on an irregular basis. While most countries seem to disagree over whether the government should take responsibility for the funding of schools that are not founded or managed by the government, policy practices and programs concerning financial assistance for such schools were universal. Examining the freedom of education around the world, Glenn and Groof (2012) found that, in addition to cases of the Netherlands and Australia mentioned above, public funding is used to support recognized nongovernment schools in Austria, Belgium, Luxemburg, Denmark, Finland, Sweden, Ireland, Norway, Iceland, Germany, New Zealand, Russia, South Africa, as well as most provinces in Canada. Meanwhile, numerous western countries-including the United States - have programs aimed at promoting education equity, reducing and eliminating socio-economic stratification, and ensuring the freedom of education. Moreover, these programs are continuing to expand their influence, as illustrated by the development and spread of education voucher programs. Although studies on the development of these programs over the past two decades have shown no significant advantage of vouchers for students attending private schools in terms of academic achievement, there is evidence indicating that students receiving vouchers graduated from high school at a higher rate than their public school counterparts and that parents of children who have received vouchers are generally more satisfied with their child's school (Center on Education Policy 2011). Studies on tuition tax credit and education savings account programs have come to similar conclusions, 
proposing that people are more satisfied with local education through their participation in these programs. These positive effects advance the promotion of policy practices and programs of financial support for non-government education around the world.

\subsection{Conclusion}

Non-government education has been shown to cultivate a wide range of public interest, make the education system healthier and more dynamic, provide various kinds of educational products and diversified educational opportunities, actively contribute to the equity of education, help make efficient use of public resources, and make education meet the needs of social and economic development. In short, non-government education is an indispensable part of the adaptation of national education to social development. As such, it is essential to provide financial support to non-government education in order to facilitate its healthy and sustainable development.

A well-designed financial support policy for non-government education will serve to increase the public interest generated by non-government schools. Ensuring the rights of non-government school students in governmental policy design will help in the construction of civil society and expand the ability of those schools to survive-as illustrated in Zhejiang Province. Moreover, the government provision of better insurance and social security care for non-government school teachers may result in those schools providing high-quality education services more efficiently than public schools - as in the Netherlands, where private schools dominate and education standards are superior. In conclusion, well-designed financial support policies will help governments achieve multiple policy objectives more effectively.

\section{References}

ACARA. (2016a). Number of schools by school type and school sector-Australia 2016. Retrieved June 20, 2017, from https://www.acara.edu.au/reporting/displayviewreport?cubeid=1\&vie wid=1.

ACARA. (2016b). Number and proportion of full-time students enrolled in schools by school level and school sectors, Australia, 2016. Retrieved June 20, 2017, from https://www.acara.edu.au/ reporting/displayviewreport?cubeid=13\&viewid=1.

ACARA (Australian Curriculum, Assessment, and Reporting Authority). (2014). National report on schooling in Australia 2013. Retrieved June 20, 2017, from http://www.acara.edu.au/ reporting/national-report-on-schooling-in-australia-2014.

Arizona Department of Revenue. (2016). Private School Tuition Organization Income Tax Credits in Arizona Summary of Activity: FY 2014/2015. Retrieved June 20, 2017, from https:// www.azdor.gov/Portals/0/Reports/FY2015\%20Private\%20School\%20Tuition\%20Org\%20 Credit\%20Report.pdf. 
Australian Government. (2013). Australian Education Act 2013. Retrieved June 20, 2017, from https://www.legislation.gov.au/Details/C2015C00112.

Australian Government Department of Education and Training. (2017). Funding for schools. Retrieved June 20, 2017, from https://www.education.gov.au/funding-schools.

Center on Education Policy. (2011). Keeping informed about school vouchers: A review of major developments and research [R]. Center on Education Policy, July 2011. Retrieved June 20, 2017, from http://files.eric.ed.gov/fulltext/ED522161.pdf.

Council for American Non-Government Education. (2015). Council for American Non-government education. Facts and studies. Retrieved June 20, 2017, from http://www.capenet.org/facts. html\#public.

EdChoice. (2016). Education savings accounts policy handout. Retrieved June 20, 2017, from https://www.edchoice.org/wp-content/uploads/2015/02/2016-8-EdChoice-ESAs1.pdf.

EdChoice. (2017). School choice: North Carolina-personal education savings accounts. Retrieved June 20, 2017, from https://www.edchoice.org/school-choice/programs/ north-carolina-personal-education-savings-accounts/.

Fang, F. (2017). Why and how to support private higher education?-Experience and enlightenment from the United States. Journal of National Academy of Education Administration, 3, 89-94.

Glenn, C. L., \& Groof, J. D. (2012). In P. E. Peterson (Ed.), Freedom and accountability: An International overview. The future of school choice. Stanford, CA: Hoover Institution Press Publication, Stanford University.

Guan, H., \& Xiao, Q. (2006). Private education: Financial support from the Government is the new tendency. Journal of the Chinese People's Political Consultative Conference, 18(C01).

Internal Revenue Service of the United States. (2017). Exemption requirements-501(c)(3) Organizations. Retrieved June 20, 2017, from https://www.irs.gov/charities-non-profits/ charitable-organizations/exemption-requirements-section-501-c-3-organizations.

Li, Y.-j., \& Zhang, H.-f. (2012). Regulations on public financial support for private education development: Foundation, limitation and improvement. Fudan Education Forum, 10(3), 72-76.

$\mathrm{Lu}$, J. (2011). Policy restrictions on and adjustment to the development of private education. Research in Educational Development, 22, 18-21.

MoE, PRC. (2002). Non-government Education Promotion Law of People's Republic of China. Retrieved July 10, 2017, from http://old.moe.gov.cn//publicfiles/business/htmlfiles/moe/ moe_619/200407/1317.html.

MoE, PRC. (2016a). Communiqué of National Education Development Statistics 2015. Retrieved July 10, 2017, from http://www.moe.gov.cn/srcsite/A03/s180/moe_633/201607/ t20160706_270976.html.

MoE, PRC. (2016b). Communiqué of the Ministry of Education, National Bureau of Statistics, Ministry of Finance on Execution Statistics of National Education Funds in 2015. Retrieved July 10, 2017, from http://www.moe.gov.cn/srcsite/A05/s3040/201611/t20161110_288422. html.

MoE, PRC. (2017). Communiqué of the Ministry of Education on National Education Finance Statistics 2016. Retrieved July 10, 2017, from http://www.moe.gov.cn/jyb_xwfb/moe_1946/ fj_2017/201705/t20170503_303596.html.

National Conference of State Legislatures. (2017). School vouchers-What states have done. Retrieved June 20, 2017, from http://www.ncsl.org/research/education/school-choice-vouchers.aspx.

National People's Congress of the People's Republic of China (2016). On the Revision of the Nongovernment Education Promotion Law by the Standing Committee of the National People's Congress. Retrieved June 20, 2017, from http://www.npc.gov.cn/npc/xinwen/2016-11/07/content_2001583.htm.

Non-government Education Association of Zhejiang Province \& China Non-government Education Research Institute Zhejiang Branch. (2011). Report on the Development of Non-government 
Education in Zhejiang Province (2004-2010). Hangzhou, Zhejiang, PRC: Zhejiang University Press.

OECD. (2012a). Public and private schools: How management and funding relate to their socio-economic profile. Paris. Retrieved June 20, 2017: OECD. https://doi. org/10.1787/9789264175006-en.

OECD. (2012b). Education at a glance 2012: OECD indicators. Retrieved June 23, 2017. https:// doi.org/10.1787/eag-2012-en.

OECD. (2016a). Netherlands 2016: Foundations for the future, reviews of national policies for education. Retrieved June 20, 2017. https://doi.org/10.1787/9789264257658-en.

OECD. (2016b). PISA 2015 results (volume I): Excellence and equity in education. Retrieved June 20, 2017, from http://www.oecd-ilibrary.org/docserver/download/9816061e.pdf?expires=150 4103318\&id=id\&accname $=$ guest $\&$ checksum $=35$ A6D101A9BAB3A118E2962520C8C26F.

Patrinos, A.H. (2010). Non-government education provision and public finance: The Netherlands. The World Bank Human Development Network, Education Team.

Pennsylvania Department of Community \& Economic Development. (2017a). Educational Improvement Tax Credit Program (EITC). Retrieved June 20, 2017, from http://dced.pa.gov/ programs/educational-improvement-tax-credit-program-eitc/.

Pennsylvania Department of Community \& Economic Development. (2017b). Opportunity Scholarship Tax Credit Program (OSTC-Previously Known As EITC 2.0). Retrieved June 20, 2017, from http://dced.pa.gov/programs/opportunity-scholarship-tax-credit-program-ostc/\#. WKYz3RhY7BK.

Snyder, T. D., de Brey, C., \& Dillow, S. A. (2016). Digest of Education Statistics 2015 (51th ed.). National Center for Education Statistics, U.S. Department of Education. Retrieved June 20, 2017, from https://nces.ed.gov/pubs2016/2016014.pdf.

State Council of the People's Republic of China. (2010). Outline of National Medium and Longterm Education Reform and Development Plan (2010-2020). Retrieved July 10, 2017, from http://www.gov.cn/jrzg/2010-07/29/content_1667143.htm.

The Foundation for Opportunity in Education. (2013). Education tax credit programs: An analysis of provisions by state. New York.

Wen, D. (2004). Modify financial policies and promote the development of private education. Private Education Research (A Bimonthly Journal), 5, 2004.

Wisconsin Department of Public Instruction. (2016). MPCP facts and figures for 2015-2016. Retrieved June 20, 2017, from https://dpi.wi.gov/sites/default/files/imce/sms/pdf/MPCP_Jan_ Facts_and_Figures_2015-16.pdf.

$\mathrm{Wu}, \mathrm{H}$. (2006). Rethinking the rights and obligations of non-government education in compulsory education. New Education, 2006(12), 1.

Wu, H. (2007a). "Zhoukou Experience" value for Chinese private education long development. Private Education Research (A Bimonthly Journal), 3, 2007.

Wu, H. (2007b). Students in non-government compulsory education schools should be equally treated in receiving financial assistance. Research in Educational Development, 29(7b), 6.

Wu, H., \& Wei, H. (2012). Why should public finance fund non-governmental education? Peking University Education Review, 10(2), 43-55.

Xie, X. (2009). Policy innovation of government public finance supporting non-governmental education development. Research in Educational Development, 15-16, 30-34.

Hua Wu professor of education policy at the Department of Education, Zhejiang University. He is the president of Institute of China Contemporary Private Education and was the founder and director of the Non-government Education Research Center of Zhejiang University. His main research interests include innovation of local education policy system, the policy system design of balanced development of compulsory education, equity in education, modern school management 
system, public-private partnership in education, theory and policy design of school cooperation, educational decision theory, etc.

Xi Wang , PhD candidate at the Department of Education, Zhejiang University. Her research interests include comparative education policy study, non-government education, equity in education, and school choice.

Open Access This chapter is licensed under the terms of the Creative Commons Attribution 4.0 International License (http://creativecommons.org/licenses/by/4.0/), which permits use, sharing, adaptation, distribution and reproduction in any medium or format, as long as you give appropriate credit to the original author(s) and the source, provide a link to the Creative Commons license and indicate if changes were made.

The images or other third party material in this chapter are included in the chapter's Creative Commons license, unless indicated otherwise in a credit line to the material. If material is not included in the chapter's Creative Commons license and your intended use is not permitted by statutory regulation or exceeds the permitted use, you will need to obtain permission directly from the copyright holder. 